\title{
Institutional violence during the parturition process in Brazil: integrative review
}

\author{
Violencia institucional durante el proceso del parto en Brasil: revisión integradora \\ Violência institucional durante o processo parturitivo no Brasil: revisão integrativa
}

\author{
Lihsieh Marrero', Odaléa Maria Brüggemann' \\ ' Universidade Federal de Santa Catarina. Florianópolis, Santa Catarina, Brazil.
}

How to cite this article:

Marrero L, Brüggemann OM. Institutional violence during the parturition process in Brazil: integrative review. Rev Bras Enferm [Internet]. 2018;71(3):1152-61. DOI: http://dx.doi.org/10.1590/0034-7167-2017-0238

\author{
Submission: 03-04-2017_Approval: 21-05-2017
}

\begin{abstract}
Objective: To identify the types of institutional violence of childbirth reported by the woman, the birth companion and health professionals. Method: Integrative review that analyzed 33 articles in the LILACS, BDENF, INDEXPSI, regional SciELO, Scopus, Web Of Science and PubMed databases. Results: Women were the main violence rapporteur, with predominance of the psychological type. Precarious infrastructure and the imposition of professional decisions were identified by the companion as violence. For health professionals, performing procedures without consent does not characterize violence, but guarantees childbirth security. Final considerations: The most common types of violence in Brazilian maternity hospitals are psychological, physical and structural. Most of the time, violence is reported by women, although professionals also perceive and admit its perpetuation.
\end{abstract}

Descriptors: Humanizing Delivery; Labor, Obstetric; Hospitals, Maternity; Health Services; Violence.

\section{RESUMO}

Objetivo: Identificar os tipos de violência institucional no parto relatados pela mulher, pelo acompanhante de parto e por profissionais de saúde. Método: Revisão integrativa que analisou 33 artigos nas bases LILACS, BDENF, INDEXPSI, SciELO regional, Scopus, Web Of Science e PubMed. Resultados: A mulher foi a principal relatora da violência, com predominância do tipo psicológica. A infraestrutura precária e a imposição das decisões profissionais foram identificadas pelo acompanhante como violência. Para os profissionais de saúde, a realização de procedimentos sem consentimento não caracteriza violência, mas garantia de segurança no parto. Considerações finais: Os tipos de violência mais comuns nas maternidades brasileiras são as psicológicas, as físicas e a estrutural. Na maioria das vezes, a violência é relatada pelas mulheres, embora profissionais também percebam e admitam sua perpetuação.

Descritores: Parto Humanizado; Trabalho de Parto; Maternidades; Serviços de Saúde; Violência.

\section{RESUMEN}

Objetivo: Identificar las clases de violencia institucional durante el parto reportadas por la mujer, por el acompañante del parto y por profesionales de la salud. Método: Revisión integradora que analizó 33 artículos en las bases LILACS, BDENF, INDEXPSI, SciELO regional, Scopus, Web Of Science y PubMed. Resultados: La mujer fue la principal informante de la violencia, con predominio del tipo psicológico. La infraestructura precaria y la imposición de las decisiones profesionales fueron identificadas por el acompañante como violencia. Para los profesionales de la salud, la realización de procedimientos sin consentimiento no caracteriza violencia, sino una garantía de seguridad en el parto. Consideraciones finales: Las clases de violencia más comunes en las maternidades brasileñas son las psicológicas, las físicas y las estructurales. La mayoría de las veces, son las mujeres quienes informan sobre la violencia, aunque los profesionales también perciban y admitan su perpetración.

Descriptores: Parto Humanizado; Trabajo de Parto; Maternidades; Servicios de Salud; Violencia.

\section{AUTOR CORRESPONDIENTE Lihsieh Marrero E-mail: lihsiehm@gmail.com}




\section{INTRODUCTION}

Mistreatment and disrespect reports to women during the parturition process in health institutions are not recent, although their elimination is a claim of social movements for human rights, which in recent years have gained visibility because of the scientific evidence on the low quality impact of care during the pregnancy-puerperal period for women and children $^{(1-2)}$. These events have promoted conceptual advances on violence in institutionalized childbirth in the legal, political, and welfare practices, shaking government agendas ${ }^{(3-4)}$.

Despite advances, there is still no clear and comprehensive definition of institutional violence in childbirth in the national and international literature, which is currently described and recognized as maltreatment and disrespect, use of procedure, conduct and routines that are harmful or have no scientific evidence during the women care in childbirth assistance services ${ }^{(5-8)}$, still frequent in many parts of the world $^{(9-10)}$. In Brazil, it is estimated that approximately $25 \%$ of the women who went through childbirth in maternities suffered some form of violence ${ }^{(11-12)}$.

The shortage of comprehensive studies that allow generalizations and estimates of magnitude, the methodological limitations of the investigations on the theme, the multifactorial and dimensional character of the phenomenon demonstrates the knowledge gaps and the necessity to increase the discussion, including different perspectives, to reveal the institutional violence aspects of childbirth.

\section{OBJECTIVE}

Identifying, in the literature, the types of institutional violence in childbirth care in Brazilian maternity hospitals reported by the woman, the birth companion and health professionals.

\section{METHOD}

This is an integrative review of the literature, whose development followed six stages ${ }^{(13)}$. The first one consisted in choosing the theme and in the elaboration of the following research questions: what are the most frequent types of institutional violence suffered by women seeking childbirth care in Brazil? Who are the subjects who report institutional violence during childbirth in investigations on this topic in Brazil?

In the second stage, inclusion and exclusion criteria were established. Only original research publications developed in Brazilian maternity hospitals were included, which recorded the occurrence in their findings, type and who reported the institutional violence that occurred during labor pains and childbirth; available in the electronic bases chosen for the study; in Portuguese, English or Spanish languages published between 2000 and 2016. Publications classified as experience reports, case studies, editorial, review and theoretical reflection were excluded from the review. Data collection was conducted between September 2016 and February 2017, in the Electronic databases Latin American and Caribbean Literature (LILACS), Nursing Database (BDENF), Index Psi Periodicals (INDEXPSI),
MEDLINE, Scientific Electronic Library Online (regional SciELO) from the Health Sciences Descriptors (DeCS) selected in the Virtual Health Library (VHL): Violence Against Women (Violência Contra a Mulher), Violence (Violência, Violencia), Hospital, Maternity (Maternidade, Maternidad), Women's Health (Saúde da Mulher), Quality improvement (Qualidade da Assistência à Saúde), Parturition (Parto, Parturição), and Obstetric (Obstetrícia, Obstetricia). The keywords "Institutional Violence" (Violência Institutional) and "Disrespect" (Desrespeito, Desprecio) were used to complement the search, with later application of the "Brazil" filter (Brazil). To search the Scopus and Web Of Science databases, the Medical Subject Headings descriptors (MeSh): "Violence", "Hospitals", "Maternity", "Parturition" and "Obstetrics" were selected from the National Library of Medicine database. The keywords "Violence Against Women", "Childbirth", "Disrespect" and "Brazil" complemented the searches. In all, 878 publications were found and 33 were eligible (Figure 1).

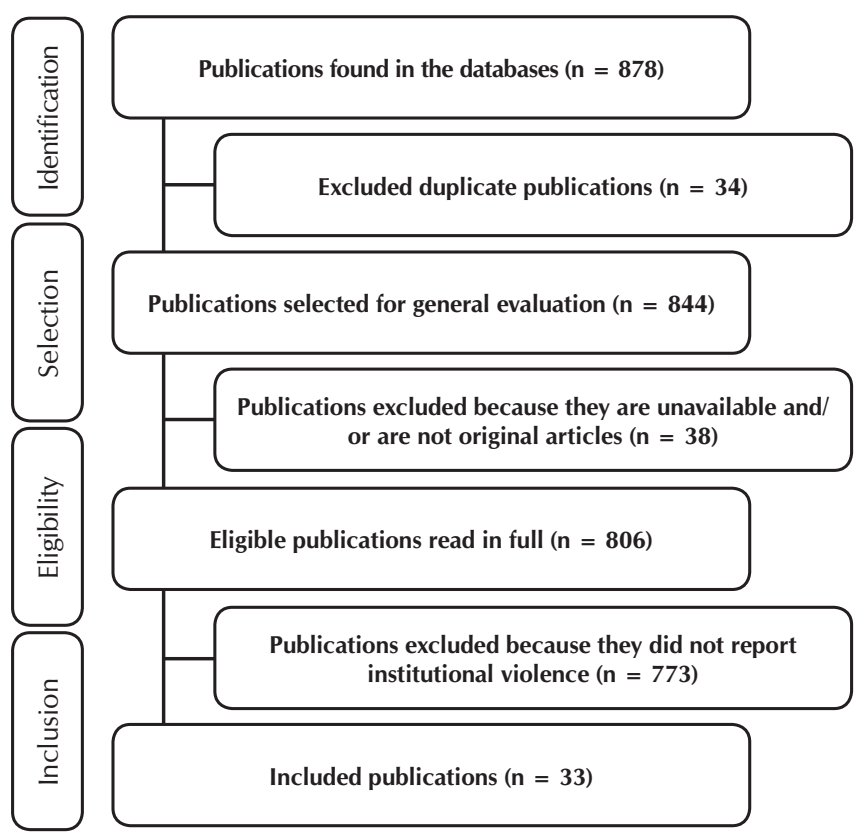

Figure 1 - Flowchart of identification and selection of publications according to PRISMA Statement

In the third stage, the data of interest (title, authors, year, journal, language, database, area of knowledge and type of publication, objectives, type of approach and research, study site, subjects and sample, data source and analysis, type, moment and report of registered institutional violence) with the aid of a previously elaborated instrument. The data were organized in Excel $^{\circledast}$ software.

In the critical analysis, the fourth stage of the study, the "double blind" methodology was used, in which two researchers evaluate the material without one knowing the opinion of the other. In the discordant cases, a third researcher proceeded to the review. The data were analyzed considering the categories of discriminatory institutional violence based on attributes (depreciation or non-care by the professional, based on racial, social 
or behavioral attributes), structural (not care and/or precarious care due to inadequate infrastructure, lack of human and material resources, lack of beds, imposition of institutional routines that violate the rights or cause damages to the parturient); verbal (rough treatment, threats, reprimand, shouting and cursing), psychological (threatening, denial of care or method of pain relief, abandonment of care, intentional humiliation, embarrassment, imposition of decisions, disqualification of women's opinion, provision of doubtful or non-informative information, trivialization/neglect of the women's suffering and needs) and physical (pushing, hurting/provoking pain upon examination, performing health-damaging procedures such as episiotomy, cesarean surgeries, administration of oxytocic and Kristeler's maneuver, restraining movements and forcing the parturient to maintain undesired positions).

The construction of these categories considered the definitions of different authors about mistreatment, abuses and violated rights of women in health institutions during the childbirth care $^{(6,8,14)}$.

In the fifth stage of the review, aimed at the discussion and interpretation of the data, the description of the typology, the moment of occurrence and by whom institutional violence at birth was reported. The summary of the evidence and the presentation of the results of the review comprised the sixth step of the methodological choice for this study.

\section{RESULTS}

The 33 articles included in this review were published between 2003 and 2016, with diffuse distribution, 66.7\% had as their language of publication only Portuguese and 30,3\% Portuguese and English. The highest percentage of publications occurred in journals from Collective Health area knowledge (57.6\%) and in the Nursing (33.3\%).

The qualitative approach was the most frequent $(78.8 \%)$, and the publications with a quantitative approach were descriptive studies. Most of the studies (93.9\%) were conducted in specific municipalities or in metropolitan areas, commonly in the Southeast (15-17) and South (78.7\%) (18-20) regions, and two had national coverage $\mathrm{e}^{(12,21)}$. The highest percentage of studies $(74 \%)$ were conducted in public institutions.

Data sources for all studies were obtained from interviews and hospital records. In $69.8 \%$ of the publications, the woman was the subject of research, victim and report of institutional violence at childbirth; in $18.1 \%$, the health professional (physician, nurses and nursing technicians) were the authors, or as witnesses of some type of violence against parturient women in their work environment; and in 3\%, the companion was the research subject (Chart 1 ). In $9.1 \%$ of the studies, institutional violence at childbirth was reported jointly by the woman, her companion and the health professional.

Chart 1 - Summary of studies included in the review, published in the period 2000 to 2016

\begin{tabular}{|c|c|c|c|c|}
\hline $\begin{array}{l}\text { Author, year and } \\
\text { approach }\end{array}$ & $\begin{array}{l}\text { Subject and sample } \\
\text { (n) of the study }\end{array}$ & Objectives of the study & $\begin{array}{c}\text { Type of reported } \\
\text { violence }\end{array}$ & $\begin{array}{c}\text { Time of violence } \\
\text { occurrence }\end{array}$ \\
\hline $\begin{array}{c}\text { Aguiar e Tanaka }^{(15)} \\
2016 \\
\text { Qualitative }\end{array}$ & Woman $(n=12)$ & $\begin{array}{l}\text { To analyze the collective memories in narratives } \\
\text { of women who lived the maternal near miss. }\end{array}$ & $\begin{array}{l}\text { Psychological } \\
\text { Physical }\end{array}$ & Delivery \\
\hline $\begin{array}{l}\text { Andrade et al. }{ }^{(22)} \\
2016 \\
\text { Quantitative }\end{array}$ & Woman $(n=603)$ & $\begin{array}{l}\text { To analyze the factors associated with practices } \\
\text { not recommended in obstetric care. }\end{array}$ & Physical & $\begin{array}{l}\text { Labor } \\
\text { Delivery }\end{array}$ \\
\hline $\begin{array}{l}\text { Belfort et al. }{ }^{(23)} \\
2016 \\
\text { Qualitative }\end{array}$ & Woman $(n=26)$ & $\begin{array}{l}\text { To describe obstetric care to black women in the } \\
\text { State of Maranhão. }\end{array}$ & $\begin{array}{l}\text { Psychological } \\
\text { Structural }\end{array}$ & $\begin{array}{l}\text { Labor } \\
\text { Delivery }\end{array}$ \\
\hline $\begin{array}{l}\text { Diniz et al. }{ }^{(16)} \\
2016 \\
\text { Quantitative }\end{array}$ & $\begin{array}{l}\text { Woman } \\
(\mathrm{n}=23.940)\end{array}$ & $\begin{array}{l}\text { To analyze socio-demographic inequalities in } \\
\text { maternity hospitals care in the Southeast Brazil. }\end{array}$ & $\begin{array}{l}\text { Psychological } \\
\text { Structural } \\
\text { Physical }\end{array}$ & $\begin{array}{l}\text { Labor } \\
\text { Delivery }\end{array}$ \\
\hline $\begin{array}{l}\text { Biscegli et al. }{ }^{(24)} \\
2015 \\
\text { Quantitative }\end{array}$ & Woman $(n=172)$ & $\begin{array}{l}\text { To verify the prevalence of obstetric violence in a } \\
\text { maternity-school. }\end{array}$ & $\begin{array}{l}\text { Psychological } \\
\text { Physical }\end{array}$ & $\begin{array}{l}\text { Labor } \\
\text { Delivery }\end{array}$ \\
\hline $\begin{array}{l}\text { Luz et al. } \\
2015 \\
\text { Qualitative }\end{array}$ & Woman $(n=11)$ & $\begin{array}{l}\text { To verify the perception of adolescents who } \\
\text { have recently given birth about the care received } \\
\text { during prenatal care and childbirth. }\end{array}$ & $\begin{array}{l}\text { Psychological } \\
\text { Physical } \\
\text { Verbal } \\
\text { Discrimination }\end{array}$ & $\begin{array}{l}\text { Labor } \\
\text { Delivery }\end{array}$ \\
\hline $\begin{array}{c}\text { Rodrigues et al. }{ }^{(26)} \\
2015 \\
\text { Qualitative }\end{array}$ & Woman $(n=56)$ & $\begin{array}{c}\text { To describe and analyze the perceptions of } \\
\text { women about obstetric care during the labor and } \\
\text { delivery process. }\end{array}$ & $\begin{array}{l}\text { Psychological } \\
\text { Structural } \\
\text { Discrimination }\end{array}$ & Admission \\
\hline $\begin{array}{l}\text { Santo et al. }{ }^{(17)} \\
2015 \\
\text { Quantitative }\end{array}$ & Woman $(n=424)$ & $\begin{array}{l}\text { To describe the socio-demographic and obstetric } \\
\text { profile of women in São Paulo. }\end{array}$ & $\begin{array}{l}\text { Psychological } \\
\text { Physical }\end{array}$ & Delivery \\
\hline
\end{tabular}

To be continued 
Chart 1

\begin{tabular}{|c|c|c|c|c|}
\hline $\begin{array}{l}\text { Author, year and } \\
\text { approach }\end{array}$ & $\begin{array}{l}\text { Subject and sample } \\
\text { (n) of the study }\end{array}$ & Objectives of the study & $\begin{array}{l}\text { Type of reported } \\
\text { violence }\end{array}$ & $\begin{array}{l}\text { Time of violence } \\
\text { occurrence }\end{array}$ \\
\hline $\begin{array}{l}\text { D'Orsi et al. }^{(21)} \\
\quad 2014 \\
\text { Quantitative }\end{array}$ & $\begin{array}{c}\text { Woman } \\
(\mathrm{n}=15.688)\end{array}$ & $\begin{array}{l}\text { To identify factors associated with the satisfaction } \\
\text { of women related to the health professionals in } \\
\text { hospital delivery and its influence on the overall } \\
\text { satisfaction of women. }\end{array}$ & $\begin{array}{l}\text { Psychological } \\
\text { Physical } \\
\text { Verbal }\end{array}$ & $\begin{array}{l}\text { Labor } \\
\text { Delivery }\end{array}$ \\
\hline $\begin{array}{l}\text { Leal et al. }{ }^{(12)} \\
2014 \\
\text { Qualitative }\end{array}$ & Woman $(n=6.740)$ & $\begin{array}{l}\text { To evaluate the use of good practices and } \\
\text { obstetric interventions. }\end{array}$ & Physical & Delivery \\
\hline $\begin{array}{c}\text { Cardoso e Barbosa }^{(27)} \\
2012 \\
\text { Qualitative }\end{array}$ & Woman $(n=15)$ & $\begin{array}{l}\text { To learn and understand, from the perception } \\
\text { of women, the mismatch between the desire for } \\
\text { vaginal delivery and the outcome in cesarean } \\
\text { section. }\end{array}$ & $\begin{array}{l}\text { Psychological } \\
\text { Structural } \\
\text { Discrimination }\end{array}$ & $\begin{array}{l}\text { Labor } \\
\text { Delivery }\end{array}$ \\
\hline $\begin{array}{l}\text { Santos e Pereira }^{(28)} \\
2012 \\
\text { Qualitative }\end{array}$ & Woman $(n=19)$ & $\begin{array}{c}\text { To understand the experiences of puerperal } \\
\text { women about the care received during the } \\
\text { parturition process in a public maternity } \\
\text { hospital. }\end{array}$ & $\begin{array}{l}\text { Psychological } \\
\text { Structural } \\
\text { Physical }\end{array}$ & $\begin{array}{l}\text { Labor } \\
\text { Delivery }\end{array}$ \\
\hline $\begin{array}{c}\text { Aguiar e } \\
\text { D'Oliveira }^{(29)} \\
2011 \\
\text { Qualitative }\end{array}$ & Woman $(n=21)$ & $\begin{array}{l}\text { To present and discuss experiences of childbirth } \\
\text { and mistreatment experienced by users in a } \\
\text { health service. }\end{array}$ & $\begin{array}{l}\text { Psychological } \\
\text { Physical } \\
\text { Verbal } \\
\text { Discrimination }\end{array}$ & $\begin{array}{l}\text { Labor } \\
\text { Delivery }\end{array}$ \\
\hline $\begin{array}{l}\text { Freire et al. }{ }^{(30)} \\
\quad 2011 \\
\text { Quantitative }\end{array}$ & Woman $(n=12)$ & $\begin{array}{l}\text { To describe women's decision making about the } \\
\text { way of delivery. }\end{array}$ & Psychological & $\begin{array}{l}\text { Labor } \\
\text { Delivery }\end{array}$ \\
\hline $\begin{array}{l}\text { Carvalho et al. }{ }^{(31)} \\
2010 \\
\text { Qualitative }\end{array}$ & $\begin{array}{l}\text { Healthcare } \\
\text { professional } \\
\quad(\mathrm{n}=23)\end{array}$ & $\begin{array}{c}\text { To identify the use of harmful practices in a } \\
\text { university hospital. }\end{array}$ & Physical & Delivery \\
\hline $\begin{array}{l}\text { Milbrath et al. }{ }^{(32)} \\
2010 \\
\text { Qualitative }\end{array}$ & Woman $(n=6)$ & $\begin{array}{l}\text { To know maternal care experiences during labor } \\
\text { and delivery. }\end{array}$ & $\begin{array}{l}\text { Psychological } \\
\text { Structural } \\
\text { Verbal }\end{array}$ & $\begin{array}{l}\text { Labor } \\
\text { Delivery }\end{array}$ \\
\hline $\begin{array}{l}\text { Wolff e Waldow } \\
2008 \\
\text { Qualitative }\end{array}$ & Woman $(n=33)$ & $\begin{array}{l}\text { To describe, analyze and discuss the } \\
\text { representations of women about parturition } \\
\text { process assistance. }\end{array}$ & $\begin{array}{l}\text { Psychological } \\
\text { Physical }\end{array}$ & Delivery \\
\hline $\begin{array}{l}\text { Carraro et al. }{ }^{(19)} \\
2006 \\
\text { Quanti-qualitative }\end{array}$ & Woman $(n=84)$ & $\begin{array}{l}\text { To assess the opinion of puerperal women about } \\
\text { care and comfort during labor and delivery. }\end{array}$ & $\begin{array}{l}\text { Psychological } \\
\text { Physical } \\
\text { Verbal }\end{array}$ & $\begin{array}{l}\text { Labor } \\
\text { Delivery }\end{array}$ \\
\hline $\begin{array}{c}\text { Dias e Deslandes } \\
2006 \\
\text { Qualitative }\end{array}$ & Woman $(n=22)$ & $\begin{array}{l}\text { To analyze expectations of pregnant women } \\
\text { about the care they will receive during childbirth } \\
\text { and the evaluation of care in previous births. }\end{array}$ & $\begin{array}{l}\text { Psychological } \\
\text { Structural } \\
\text { Physical } \\
\text { Verbal }\end{array}$ & $\begin{array}{l}\text { Labor } \\
\text { Delivery }\end{array}$ \\
\hline $\begin{array}{c}\text { McCallum, e Reis }{ }^{(35)} \\
2006 \\
\text { Qualitative }\end{array}$ & Woman $(n=26)$ & $\begin{array}{l}\text { To examine childbirth in a public maternity } \\
\text { hospital based on the perspective of young } \\
\text { women and adolescents. }\end{array}$ & $\begin{array}{l}\text { Psychological } \\
\text { Structural } \\
\text { Physical } \\
\text { Verbal } \\
\text { Discrimination }\end{array}$ & $\begin{array}{l}\text { Labor } \\
\text { Delivery }\end{array}$ \\
\hline $\begin{array}{c}\text { Teixeira e Pereira }{ }^{(36)} \\
2006 \\
\text { Qualitative }\end{array}$ & Woman $(n=10)$ & $\begin{array}{l}\text { To analyze cultural aspects of experiences of } \\
\text { women who had normal hospital delivery. }\end{array}$ & $\begin{array}{l}\text { Psychological } \\
\text { Physical }\end{array}$ & $\begin{array}{l}\text { Labor } \\
\text { Delivery }\end{array}$ \\
\hline $\begin{array}{l}\text { Leal et al. }{ }^{(37)} \\
2005 \\
\text { Qualitative }\end{array}$ & Woman $(\mathrm{n}=9.633)$ & $\begin{array}{c}\text { To analyze the social inequalities of access to the } \\
\text { delivery service. }\end{array}$ & Estrutural & $\begin{array}{l}\text { Admission } \\
\text { Labor } \\
\text { Delivery }\end{array}$ \\
\hline $\begin{array}{c}\text { Domingues et al. }{ }^{(38)} \\
2004 \\
\text { Qualitative }\end{array}$ & Woman $(n=246)$ & $\begin{array}{l}\text { To analyze factors associated with the } \\
\text { satisfaction of women with attention to normal } \\
\text { childbirth in maternity. }\end{array}$ & $\begin{array}{l}\text { Psychological } \\
\text { Structural } \\
\text { Physical } \\
\text { Verbal }\end{array}$ & $\begin{array}{l}\text { Labor } \\
\text { Delivery }\end{array}$ \\
\hline
\end{tabular}


Chart 1 (concluded)

\begin{tabular}{|c|c|c|c|c|}
\hline $\begin{array}{l}\text { Author, year and } \\
\text { approach }\end{array}$ & $\begin{array}{l}\text { Subject and sample } \\
\text { (n) of the study }\end{array}$ & Objectives of the study & $\begin{array}{l}\text { Type of reported } \\
\text { violence }\end{array}$ & $\begin{array}{l}\text { Time of violence } \\
\text { occurrence }\end{array}$ \\
\hline $\begin{array}{l}\text { Tornquist } \\
2003 \\
\text { Qualitative }\end{array}$ & Woman $(n=27)$ & $\begin{array}{l}\text { To investigate obstetrical care on respect for } \\
\text { human rights, cultural and social differences and } \\
\text { good practices. }\end{array}$ & $\begin{array}{l}\text { Psychological } \\
\text { Física }\end{array}$ & Delivery \\
\hline $\begin{array}{l}\text { Brüggemann et al. }{ }^{(40)} \\
2016 . \\
\text { Qualitative }\end{array}$ & $\begin{array}{l}\text { Healthcare } \\
\text { professional } \\
\quad(n=17)\end{array}$ & $\begin{array}{l}\text { To unveil the possibilities of the companion } \\
\text { insertion in childbirth in public or contracted } \\
\text { institutions. }\end{array}$ & $\begin{array}{l}\text { Psychological } \\
\text { Structural }\end{array}$ & $\begin{array}{l}\text { Labor } \\
\text { Delivery }\end{array}$ \\
\hline $\begin{array}{l}\text { De Aguiar et al. }{ }^{(41)} \\
2013 \\
\text { Qualitative }\end{array}$ & $\begin{array}{l}\text { Healthcare } \\
\text { professional } \\
\quad(\mathrm{n}=18)\end{array}$ & $\begin{array}{l}\text { To present and discuss institutional violence } \\
\text { from the point of view of health professionals in } \\
\text { public maternity hospitals. }\end{array}$ & $\begin{array}{l}\text { Psychological } \\
\text { Structural } \\
\text { Verbal } \\
\text { Discrimination }\end{array}$ & $\begin{array}{l}\text { Labor } \\
\text { Delivery }\end{array}$ \\
\hline $\begin{array}{l}\text { Carvalho et al. }{ }^{(31)} \\
2012 \\
\text { Quantitative }\end{array}$ & $\begin{array}{l}\text { Healthcare } \\
\text { professional } \\
\quad(\mathrm{n}=23)\end{array}$ & $\begin{array}{l}\text { To know the justification of professionals for the } \\
\text { use of harmful practices at birth. }\end{array}$ & $\begin{array}{l}\text { Psychological } \\
\text { Structural }\end{array}$ & $\begin{array}{l}\text { Labor } \\
\text { Delivery }\end{array}$ \\
\hline $\begin{array}{l}\text { Busanello et al. }^{(42)} \\
2011 \\
\text { Qualitative }\end{array}$ & $\begin{array}{l}\text { Healthcare } \\
\text { professional } \\
\quad(n=23)\end{array}$ & $\begin{array}{l}\text { To analyze the conceptions of professionals } \\
\text { about obstetric assistance to adolescents. }\end{array}$ & $\begin{array}{l}\text { Psychological } \\
\text { Structural }\end{array}$ & Delivery \\
\hline $\begin{array}{l}\text { Ângulo-Tuesta et al. }{ }^{(20)} \\
2003 \\
\text { Qualitative }\end{array}$ & $\begin{array}{l}\text { Healthcare } \\
\text { professional } \\
\quad(\mathrm{n}=35)\end{array}$ & $\begin{array}{l}\text { To understand the representations of } \\
\text { obstetricians and nurses about teamwork in the } \\
\text { parturient care. }\end{array}$ & $\begin{array}{l}\text { Psychological } \\
\text { Structural } \\
\text { Physical Verbal. }\end{array}$ & Delivery \\
\hline $\begin{array}{l}\text { Resende et al. }{ }^{(43)} \\
2015 \\
\text { Qualitative }\end{array}$ & $\begin{array}{l}\text { Companion } \\
\qquad(\mathrm{n}=11)\end{array}$ & $\begin{array}{c}\text { To know the relatives' perception of } \\
\text { women victims of maternal death and their } \\
\text { circumstances. }\end{array}$ & $\begin{array}{l}\text { Psychological } \\
\text { Structural } \\
\text { Discriminatória }\end{array}$ & $\begin{array}{l}\text { Admission } \\
\text { Labor } \\
\text { Delivery }\end{array}$ \\
\hline $\begin{array}{l}\text { Souza e Gualda }{ }^{(44)} \\
2016 \\
\text { Qualitative }\end{array}$ & $\begin{array}{c}\text { Companion } \\
(n=11) \\
\text { Woman }(n=11)\end{array}$ & $\begin{array}{l}\text { To know the experience of women and their } \\
\text { companions in the process of childbirth. }\end{array}$ & $\begin{array}{l}\text { Psychological } \\
\text { Structural } \\
\text { Physical }\end{array}$ & $\begin{array}{l}\text { Labor } \\
\text { Delivery }\end{array}$ \\
\hline $\begin{array}{l}\text { Reis e Patrício } \\
2005 \\
\text { Qualitative }\end{array}$ & $\begin{array}{c}\text { Companion } \\
(n=11) \\
\text { Woman }(n=11) \\
\text { Healthcare } \\
\text { professional } \\
(n=10)\end{array}$ & $\begin{array}{c}\text { To analyze the application of the recommended } \\
\text { actions for the humanized delivery in a General } \\
\text { Hospital of Santa Catarina. }\end{array}$ & $\begin{array}{l}\text { Psychological } \\
\text { Structural } \\
\text { Physical }\end{array}$ & $\begin{array}{l}\text { Labor } \\
\text { Delivery }\end{array}$ \\
\hline $\begin{array}{l}\text { Lino e Diniz }^{(46)} \\
2015 \\
\text { Qualitative }\end{array}$ & $\begin{array}{l}\text { Woman }(n=14) \\
\text { Healthcare } \\
\text { professional } \\
(n=14)\end{array}$ & $\begin{array}{l}\text { To describe the perceptions of health } \\
\text { professionals and private sector users about } \\
\text { childbirth and contributing factors. }\end{array}$ & $\begin{array}{l}\text { Psychological } \\
\text { Structural } \\
\text { Discriminatória }\end{array}$ & Delivery \\
\hline
\end{tabular}

The set characterization of the selected studies brings the reader closer to the reality of childbirth care in Brazilian institutions. The methodological restriction of the studies suggests the need to extend the discussion about institutional violence in childbirth, revealing its forms, aggressors and the perception of victims and witnesses. The synthesis of the analyzed data is presented in two parts for a better understanding of the results.

Institutional violence: typology and moments of occurrence in the daily life of Brazilian maternity hospitals

The selected studies show that in the Brazilian birthing scenario, institutional violence of the psychological type was the most frequent $(84.8 \%)$, followed by structural $(57.6 \%)$ and physical $(57.6 \%)$. Verbal (30.3\%) and discriminatory $(27.2 \%)$ violence were reported in a lower percentage. In most of the publications, more than one type of violence was recorded, showing concomitant occurrences. Sexual violence was not recorded in any of the studies.

In $9.1 \%$ of the studies, the results showed that institutional violence began before the woman's hospitalization and lasted until delivery $(93.1 \%)$. The type of institutional violence that occurs before the woman is admitted to childbirth is usually structural, reported as a pilgrimage in the search for care due to the insufficiency of the obstetric bed in the institutions ${ }^{(26,43)}$. Discriminatory violence motivated by women's social class was also described, although in a lower percentage $(17.2 \%)^{(16,32,37)}$.

The studies showed that psychological aggressions against women were predominant in labor and delivery $(75.9 \%$ and $82.8 \%$, respectively). The companion's absence $(51.7 \%)$, the neglect of the parturient needs by the care team (37.9\%) and the imposition of the team's decisions on care were reported as a significant percentage of the investigations $(34.5 \%)^{(12,28,33)}$. 
The constraint (13.7\%), caused by lack of privacy during labor and delivery, and professional constraint for cesarean surgery $(10.3 \%)$ were also identified ${ }^{(24,30,39)}$.

Physical violence in labor and delivery $(62.1 \%$ and $65.5 \%$, respectively), identified by the research subject, was characterized as an obstetric practice not recommended by the scientific evidence ${ }^{(17,21,34,36)}$.

The structural violence referred during labor and delivery $(55.2 \%)$ was described as physical structure inadequacy of the institutions attendance $(17.2 \%)$, the imposition of institutional routines that disregard the needs and rights of parturient women $(13,8 \%)$ and staff deficit $(10.3 \%)$ to provide decent and quality care at childbirth ${ }^{(29,35,40)}$. The bad qualification of the care team, the conflict between professional classes and the lack of material resources to attend delivery were also pointed out as institutional violence, although in a smaller number of $\operatorname{studies}^{(32,42,45)}$.

Interpretations of women, companions and health professionals about institutional violence at childbirth

In the studies in which the women were the subjects of the research, the violence of the psychological type was the most reported $(87 \%)$, the absence of the companion was the main reason for the feeling of violation. For those attended in public maternity hospitals, the obstruction of the presence of the companion of their choice during labor and delivery also generated insecurity, fear and loneliness, transforming the experience into a violent, unpleasant and suffered one $\mathrm{e}^{(25,38,44)}$.

Institutional violence, in the embarrassment form, due to the lack of privacy because of the physical structure limitations of the health institution and exposure for didactic purposes, emerges among women who gave birth in public and teaching maternities ${ }^{(24,29,33)}$. It is also worth mentioning the reports of professional coercion for delivery through cesarean surgery such as psychological violence, marked by the provision of false information, threats and disqualification of women's decisions, without differences between social class or type of service provider ${ }^{(27,29-30)}$.

Women's reports of some form of physical violence during childbirth were identified in $74 \%$ of the studies. The obstetric practices advised to be avoided by scientific evidence (episiotomy, Kristeler and use of oocytes) were frequently (86.9\%) perceived by women as aggressions. Feelings of agression were also recorded in situations where the pain relief was denied $(26.1 \%)$ and the obligation to adopt the lithotomy position at delivery $(17.4 \%)$. Repeated and painful touches and the precariousness of communication between professionals and users were perceived by the parturient women as institutional violence.

Structural violence was reported as an inadequate infrastructure for attending childbirth and companion receiving $(52.1 \%)$ and as institutional routines $(17.4 \%)$ that violate the law and violate their rights. This type of violence was common in public health care visits ${ }^{(18,23)}$.

In the small number of studies that had the companion as a rapporteur of institutional violence in childbirth, they all referred to psychological and structural violence ${ }^{(40,44-45)}$. In their speeches, the companions demonstrate that they understand the imposition of the professionals' decisions during childbirth as opportunistic, given the emotional fragility of the woman, and the use of the welfare of the fetus as a bargain. The precariousness infrastructure of institutions that do not guarantee women privacy, impose limits to the companion's continuous presence and the insufficiency of obstetric beds were perceived as institutional violence, as it impairs the dignified and safe care of the woman and the newborn.

The studies carried out in which the health professional was the rapporteur on institutional violence at childbirth (8), showed that violence of the psychological and structural types is perceived more frequently $(71.4 \%)$, followed by physical violence $(42.9 \%)$. Attitudes such as increased tone of voice and harshness, deprivation imposition (of ingestion and emotional support) to the parturient and the abandonment threat of care are part of the routine care of many institutions and, although recognized as violence, are considered necessary for the order, professional authority and the well-being of women and the concept, especially in public maternity hospitals ${ }^{(18,31,41,45)}$.

From the professionals' point of view, in public institutions the situation is aggravated by structural violence, which victimizes not only women but also health workers, since it imposes overload and accumulation of working hours, remuneration and unsatisfactory working conditions. The discontinuity between prenatal, delivery and postpartum follow-up, the access difficulty to labor services, the lack of structure to accommodate the companion in the parturition process, and the frequent unavailability of medications for proper management of pain are examples of structural institutional violence, pointed out by health professionals ${ }^{(19-20,22)}$.

The restriction of parturient movement at birth and the procedure performances without consent or explanation, as well as the use of techniques discouraged by scientific evidence, were not perceived by the professionals as physical violence, but as a guarantee of security, supported by the professional authority, especially the physician ${ }^{(31,46)}$.

\section{DISCUSSION}

The diverse typology, moments of occurrence, interpretations and actors involved in situations of violence in institutionalized childbirth demonstrate the multidimensional and multifactorial character of the phenomenon.

The institutional routines and professional-centered care practices employed in women's care who seek for childbirth services are understood as psychological, physical and verbal aggressions $^{(28,44)}$. However, professionals and managers understand these actions/attitudes as a means of guaranteeing safety and quality of care for the woman and the newborn, although they do not deny the need for care improvements, either in access, infrastructure of maternity wards or in professional qualification ${ }^{(41,45)}$.

The different interpretations about institutional violence in childbirth care restart the discussion about the inequality of power between users and health professionals $s^{(15,27,30,41)}$. We have observed that the interactions between providers and users of Brazilian health services, especially in public management institutions, are marked by professional authoritarianism that can be attributed, in parts, to the maintenance of 
social and racial hierarchies, reflected in the current professional training process. During the learning of health profession careers, students conduct their technical skills training in health services, preferably in institutions, where the majority of the users are poor and of ethnic minorities. Patients are seen as object of training, whereas abuse, such as unnecessary or unsatisfactory interventions, ill-treatment, disrespect and their consequences are not recognized as violations of rights ${ }^{(16)}$. The authoritarian and interventionist professional training brings consequences to how care is provided to the parturient, often understood by them and their companions as negligence, violence and, often, discrimination, whether in public or private institutions ${ }^{(12,23,28)}$.

The labor pain naturalization results in the denial or nonoffer of pain relief methods, neglect of demands, abandonment and disqualification of women's opinions, as well as non-sharing of information for decision making on childbirth, are subtle forms of institutional violence, camouflaged in care routines in Brazilian maternity hospitals, accepted by professionals, women and companions ${ }^{(30,36)}$. The voluntary submission of parturient women to the professional impositions on their bodies and behaviors during the institutionalized childbirth can be explained by the Governability exercise. Governability, conceptually, one of the orders of power, which structures action, leads the individuals or groups to a conduct as subjects of action, even though it does not guarantee harmony in interpersonal interactions, nor does it prevent the occurrence of violence in care practices ${ }^{(47)}$.

Ethnic-social differences as motivators of violence against women in the pregnancy-puerperal cycle goes back decades and are recognized worldwide, being a theme in negotiation forums on international politics (International Convention on the Elimination of All Forms of Discrimination against Women, 1979, International Conference on Safe Maternity, 1987, International Conference on Population and Development, 1994, World Conference on Women, 1995). Unequal access to care services and poor quality of care are also forms of institutional violence of the structural type, produced by the neglect of the state and translated as social and gender discrimination ${ }^{(48)}$.

Regarding the efforts to change, the initiatives of the Brazilian government and social movements cannot be denied towards reorienting obstetric care, fewer interventionist care practices, and enabling new professionals to attend childbirth. However, the practices review meets opposition within medical professionals resistance and their representative entities, which present as arguments the low qualification of non-medical professionals and the doubt for their technical competencies for conducting safe childbirth ${ }^{(6)}$, despite the opposite evidence ${ }^{(49-50)}$.

The presentation of new actors as the companion of women's choice, as well as the greater need of the parturient for their autonomy and role in institutionalized childbirth has been impaired by institutional structures that are moralistic and centered on the health professional(12), and result in subtle forms of violence during the women care in the parturition process. Although the ministerial recommendations for childbirth and childbirth care are based on the best scientific evidence and social appeal for safe and non-violent motherhood, it is necessary to restructure the network of childbirth care and professional health training, directed by the respect and rights women must have during childbirth.

\section{Limitations of the study}

The difficulty of approaching the theme is presented as a major limitation according to this study, due to its controversy, which results in a small number of publications. The level of evidence from the included publications, mostly at level 4, makes it difficult to conclude the types, timing, and actors involved in situations of institutional violence at childbirth. The disparity between investigations that had the parturient as subject, the childbirth companion and the health professional limits the understanding of the problem.

Contributions to the area of Nursing, health or public policy

The results of the study may support proposals for the reorientation of practices and policies aimed at assisting institutionalized childbirth, drawing attention to problems that have existed for decades. This is because the presentation of the problem from different perspectives is a fundamental point for reflection on reality and about what is intended for the woman's care during childbirth. The gap between policy, legislation and obstetric care needs to be reduced, and it is essential to know the problem in its multiple dimensions, scenarios, actors and factors involved, as presented in this study, for the elaboration and implementation of effective measures and actions against institutional violence in childbirth in Brazilian maternity hospitals.

\section{FINAL CONSIDERATIONS}

The analysis of the set of studies shows that psychological, physical and structural institutional violence in childbirth are the most common in Brazilian maternity hospitals, most often reported by women, although professionals also perceive and admit their perpetration. The companion was the subject of an insignificant percentage of studies, although s/he is one of the actors in the childbirth scenario with proven benefits stated by the scientific evidence, with potential for the institutional violence prevention, it demonstrates the need to deepen and expand the investigations with the purpose to increase the knowledge about the problem.

Social and political appeals, based on scientific evidence, for a safe and non-violent motherhood have grown in the country, imposing the need to discuss the different forms of institutional violence in childbirth, related factors and effective measures for their prevention.

Given the multifactorial feature of institutional violence in childbirth, different segments of society (governments, civil society, health workers' class, training institutes, and researchers) should discuss building effective policies and guidelines to address the problem. Because one of the institutional violence side of childbirth is the structural one, which evokes The State Administration to act more vigorously in its prevention, expanding access to quality childbirth services with adequate infrastructure, adequate human resources and materials; and 
public power in the creation of legal and social devices that allow women's equality and dignity living.

Researches on the subject are still timid and restricted to local studies, with no robustness to support generalizations. In addition, the studies have not explored the different perspectives of institutional violence in childbirth; as an example is the absence of studies that have as subject the companion of choice and the occurrence of institutional violence has been seen in childbirth or suffering.

In this sense, proposals for deeper, broader research and with different methods on the subject are necessary to better explore the problem, and thus enabling, to contribute to the elaboration of policies, actions and social and legal devices for the elimination of institutional violence during childbirth.

\section{REFERENCES}

1. Mmusi-Phetoe RMM. Social factors determining maternal and neonatal mortality in South Africa: A qualitative study. Curationis [Internet]. 2016 [cited 2016 Aug 24];39(1):1-8. Available from: http://www.curationis.org.za/index.php/curationis/article/ view/1571/1977

2. Lansky S, Fricher AAL, Silva AAM, Campos D, Bittencourt DAS, Carvalho ML, et al. Pesquisa Nascer no Brasil: perfil da mortalidade neonatal e avaliação da assistência à gestante e ao recém-nascido. Cad Saúde Pública [Internet]. 2014 [cited 2016 Aug 24];30(Sup):S192-207. Available from: http://www.scielo.br/pdf/csp/v30s1/en_0102-311X-csp-30-s1-0192.pdf

3. Lukasse M, Schroll AM, Karro H, Schei B, Steingrimsdottir T, Van Parys AS, et al. Prevalence of experienced abuse in healthcare and associated obstetric characteristics in six European countries. Acta Obstet Gynecol Scand Suppl [Internet]. 2015 [cited 2016 Sep 09]; 94:508-17. Available from: http://onlinelibrary.wiley.com/doi/10.1111/aogs.12593/abstract;jsessionid = 8C9B4942700 5964EEE4A3370E5AC6A3E.f02t02

4. Vázquez-Parra JC. Abuso de la operación cesárea y el principio de beneficencia. Rev Latinoam Bioet [Internet]. 2016 [cited 2016 Aug 24];16(1):60-71. Available from: https://repositorio.itesm.mx/ortec/bitstream/11285/627866/1/Latinoamericana + de + Bio\%C $3 \%$ A9tica.pdf

5. Diniz CSG, Batista LE, Kalckmann S, Schlithz AOC, Queiroz MR, Carvalho PCA. Desigualdades sociodemográficas e na assistência à maternidade entre puérperas no Sudeste do Brasil segundo cor da pele: dados do inquérito nacional Nascer no Brasil (20112012). Saude Soc [Internet]. 2016 [cited 2017 Jan 08];25(3):561-72. Available from: http://www.scielo.br/pdf/sausoc/v25n3/19840470-sausoc-25-03-00561.pdf

6. Tesser CD, Knobel R, Andrezzo HFA, Diniz SG. Violência obstétrica e prevenção quaternária: o que é e o que fazer. Rev Bras Med Fam Comunidade [Internet]. 2015 [cited 2016 Nov 08];10(35):1-12. Available from: https://rbmfc.org.br/rbmfc/article/ view/1013/716

7. Organização Mundial da Saúde. Prevenção e eliminação de abusos, desrespeito e maus-tratos durante o parto em instituições de saúde [Internet]. Genebra: Organização Mundial da Saúde, 2014[cited 2016 Nov 08]. Available from: http://apps.who.int/iris/ bitstream/10665/134588/3/WHO_RHR_14.23_por.pdf

8. Bowser D, Hill K. Exploring Evidence for Disrespect and Abuse in Facility-based Childbirth: report of a landscape analysis [Internet]. USAID / Traction Project; 2010[cited 2016 Nov 08]. Available from: http: http://www.tractionproject.org/resources/ access-skilled-care-respectful-maternal-care/exploring-evidence-disrespect-and-abuse

9. Diaz-Tello F. Invisible wounds: obstetric violence in the United States. Reprod Health Matters [Internet]. 2016 [cited 2016 Oct 06];24:56-64. Available from: http://www.tandfonline.com/doi/full/10.1016/j.rhm.2016.04.004

10. Okafor I, Ugwu EO, Obi SN. Disrespect and abuse during facility-based childbirth in a low-income country. Obstet Gynecol Int J [Internet]. 2015 [cited 2016 Sep 09];128:110-13. Available from: http://obgyn.onlinelibrary.wiley.com/hub/ journal/10.1002(issn)1879-3479/call-for-papers/ijgo-latin-america.html?campaign = dartwol |4378545978

11. Venturi G, Bokany V, Dias R. Mulheres brasileiras e gênero nos espaços público e privado [Internet]. São Paulo: Fundação Perseu Abramo/Sesc, 2010. [cited 2016 Aug 21]. Available from: http://csbh.fpabramo.org.br/sites/default/files/pesquisaintegra.pdf

12. Leal MC, Pereira APE, Domingues RMSM, Theme Filha MM, Dias MAB, Nakamura-Pereira M, et al. Obstetric interventions during labor and childbirth in Brazilian low-risk women. Cad Saude Publica [Internet]. 2014 [cited 2016 Sep 09];30(Sup):S17-47. Available from: http://www.scielo.br/pdf/csp/v30s1/en_0102-311X-csp-30-s1-0017.pdf

13. Whittemore R, Knafl K. The integrative review: update methodology. J Adv Nurs [Internet]. 2005 [cited 2016 Aug 21];52(5):54653. Available from: http://onlinelibrary.wiley.com/doi/10.1111/j.1365-2648.2005.03621.x/abstract

14. D'Oliveira AFPL, Diniz CSG, Schraiber LB. Violence against women in health-care institutions: an emerging problem. Lancet [Internet]. 2002 [cited 2016 Aug 21];359(11):1681-5. Available from: http://www.thelancet.com/journals/lancet/article/PIIS0140-6736(02)08592-6/ fulltext

15. Aguiar CA, Tanaka ACA. Memórias coletivas de mulheres que vivenciaram o near miss materno: necessidades de saúde e direitos humanos. Cad Saude Publica [Internet]. 2016 [cited 2016 Aug 21];32(9):e00161215. Available from: http://www.scielo.br/pdf/ csp/v32n9/1678-4464-csp-32-09-e00161215.pdf

16. Diniz SG, Niy DY, Andrezzo HAA, Carvalho PCA, Salgado HO. A vagina-escola: seminário interdisciplinar sobre violência contra 
a mulher no ensino das profissões de saúde. Interface [Internet]. 2016 [cited 2016 Aug 24];20(56):253-9. Available from: http:// www.scielo.br/pdf/icse/v20n56/1807-5762-icse-20-56-0253.pdf

17. Santos JO, Pacheco TS, Oliveira PS, Pinto VL, Gabrielloni MC, Barbieri M. Perfil obstétrico e neonatal de puérperas atendidas em maternidades de São Paulo. J Res Fundam Care [Internet]. 2015 [cited 2017 Mar 08];7(1):1936-45. Available from: http://www. redalyc.org/pdf/5057/505750945018.pdf

18. Carvalho VF, Kerber NPC, Busanello J, Gonçalves BG, Rodrigues EF, Azambuja EP. Como os trabalhadores de um Centro Obstétrico justificam a utilização de práticas prejudiciais ao parto normal. Rev Esc Enferm USP [Internet]. 2012 [cited 2017 Mar 01];46(1):30-7. Available from: https://www.revistas.usp.br/reeusp/article/viewFile/40914/44395

19. Carraro TE, Knobel R, Radünz V, Meincke SMK, Fiewski MFC, Meincke SMK, Fiewski MFC, Frello AT, Martins MS, Lopes CV, Berton A. Cuidado e conforto durante o trabalho de parto e parto: na busca pela opinião das mulheres. Texto Contexto Enferm [Internet]. 2006 [cited 2016 Dec 01];15(esp):97-104. Available from: http://www.scielo.br/pdf/tce/v15nspe/v15nspea11

20. Ângulo-Tuesta A, Giffin K, Gama AS, D'orsi E, Barbosa G. Saberes e práticas de enfermeiros e obstetras: cooperação e conflito na assistência ao parto. Cad Saude Publica [Internet]. 2003[cited 2016 Dec 01];19(5):1425-36. Available from: http://www.scielo.br/ $\mathrm{pdf} / \mathrm{csp} / \mathrm{v} 19 \mathrm{n} 5 / 17815 . \mathrm{pdf}$

21. D'orsi E, Brüggemann OM, Diniz CSG, Aguiar JM, Gusman CR, Torres JA, et al. Desigualdades sociais e satisfação das mulheres com o atendimento ao parto no Brasil: estudo nacional de base hospitalar. Cad Saude Publica [Internet]. 2014 [cited 2016 Dec 01];30(Supl):S154-68. Available from: http://www.scielo.br/pdf/csp/v30s1/en_0102-311X-csp-30-s1-0154.pdf

22. Andrade PON, Silva JQP, Diniz CMM, Caminha MFC. Fatores associados à violência obstétrica na assistência ao parto vaginal em uma maternidade de alta complexidade em Recife, Pernambuco. Rev Bras Saude Matern Infant [Internet]. 2016 [cited 2017 Feb 02];16(1):29-37. Available from: http://www.scielo.br/pdf/rbsmi/v16n1/1519-3829-rbsmi-16-01-0029.pdf

23. Belfort IKP, Kalckmann S, Batista LE. Assistência ao parto de mulheres negras em um hospital do interior do Maranhão, Brasil. Saude Soc [Internet]. 2016 [cited 2016 Sep 18];25(3):631-40. Available from: http://www.scielo.br/pdf/sausoc/v25n3/1984-0470sausoc-25-03-00631.pdf

24. Biscegli TS, Grio JM, Melles LC, Ribeiro SRMI, Gonsaga RAT. Violência obstétrica: perfil assistencial de uma maternidade-escola do interior do Estado de São Paulo. Cuidarte Enferm [Internet]. 2015 [cited 2016 Sep 05];9(1):18-25. Available from: http:// fundacaopadrealbino.org.br/facfipa/ner/pdf/Revistacuidarteenfermagem\%20v. \%209\% 20n.1\%20\%20jan. \% 20jun \% 202015.pdf

25. Luz NF, Assis TR, Rezende FR. Puérperas adolescentes: percepções relacionadas ao pré-natal e ao parto. ABCS Health Sci [Internet]. 2015 [cited 2017 Feb 02];40(2):80-4. Available from: https://www.portalnepas.org.br/abcshs/article/view/735

26. Rodrigues DP, Alves VH, Penna LHG, Pereira AV, Branco MBLR, Silva LA. A peregrinação no período reprodutivo: uma violência no campo obstétrico. Esc Anna Nery Rev Enferm [Internet]. 2015 [cited 2016 Aug 24];19(4):614-20. Available from: http://www. scielo.br/pdf/ean/v19n4/1414-8145-ean-19-04-0614.pdf

27. Cardoso JE, Barbosa RHS. O desencontro entre desejo e realidade: a "indústria" da cesariana entre mulheres de camadas médias no Rio de Janeiro, Brasil. Physis [Internet]. 2012 [cited 2016 Aug 28];22(1):35-52. Available from: http://www.scielo.br/pdf/physis/ v22n1/v22n1a03.pdf

28. Santos LM, Pereira SSC. Vivências de mulheres sobre a Assistência recebida no processo parturitivo. Physis [Internet]. 2012 [cited 2016 Oct 17];22(1):77-97. Available from: http://www.scielo.br/pdf/physis/v22n1/v22n1a05.pdf

29. Aguiar JM, D'Oliveira AFPL. Violência institucional em maternidades públicas sob a ótica das usuárias. Interface [Internet]. 2011 [cited 2016 Aug 21];15(36):79-91. Available from: http://www.scielo.br/pdf/icse/2010nahead/aop4010

30. Freire NC, Nunes IM, Almeida MS, Gramacho RCCV. Parto normal ou cesárea? a decisão na voz das mulheres. RBE [Internet]. 2011 [cited 2016 Oct 15];25(3):237-47. Available from: https://portalseer.ufba.br/index.php/enfermagem/article/view/6027

31. Carvalho VF, Kerber NPC, Busanello J, Costa MMG, Gonçalves BG, Quadros VF. Práticas prejudiciais ao parto: relato dos trabalhadores de sul do Brasil. Rev Rene [Internet]. 2010 [cited 2017 Jan 03];11:92-8. Available from: http://www.revistarene.ufc. br/revista/index.php/revista/article/view/466

32. Milbrath VM, Amestoy SC, Soares DC, Siqueira HCH. Vivências maternas sobre a assistência recebida no processo de parturição. Esc Anna Nery Rev Enferm [Internet]. 2010 [cited 2017 Jan 03];14(3):462-7. Available from: http://www.scielo.br/pdf/ean/v14n3/ v14n3a05.pdf

33. Wolff LR, Waldow VR. Violência Consentida: mulheres em trabalho de parto e parto. Saude Soc. 2008 [cited 2016 Aug 24];17(3):138-51. Available from: http://www.scielo.br/pdf/sausoc/v17n3/14.pdf

34. Dias MAB, Deslandes SF. Expectativas sobre a assistência ao parto de mulheres usuárias de uma maternidade pública do Rio de Janeiro, Brasil: os desafios de uma política pública de humanização da assistência. Cad Saude Publica [Internet]. 2006 [cited 2016 Aug 24];22(12):2647-55. Available from: https://www.arca.fiocruz.br/bitstream/icict/347/1/Expectativas $\% 20$ sobre $\% 20$ a $\% 20$ assistencia_2006.pdf

35. McCallum C, Reis AP. Re-significando a dor e superando a solidão: experiências do parto entre adolescentes de classes populares atendidas em uma maternidade pública de Salvador, Bahia, Brasil. Cad Saude Publica [Internet]. 2006 [cited 2016 Aug 24];22(7):1483-91. Available from: http://www.scielo.br/pdf/csp/v22n7/12.pdf

36. Teixeira NZF, Pereira WR. Parto hospitalar: experiências de mulheres da periferia de Cuiabá-MT. Rev Bras Enferm [Internet]. 
2006[cited 2016 Aug 24];59(6):740-4. Available from: http://www.scielo.br/pdf/reben/v59n6/a04.pdf

37. Leal MC, Gama SGN, Cunha CB. Desigualdades raciais, sociodemográficas e na assistência ao pré-natal e ao parto, 1999-2001. Rev Saude Publica [Internet]. 2005[cited 2016 Aug 24];39(1):100-7. Available from: http://www.scielo.br/pdf/rsp/v39n1/en_13.pdf

38. Domingues RMSM, Santos EM, Leal MC. Aspectos da satisfação das mulheres com a assistência ao parto: contribuição para o debate. Cad Saude Publica [Internet]. 2004[cited 2016 Aug 24];20(Supl1):S52-62. Available from: http://www.scielo.br/pdf/csp/ v20s1/06.pdf

39. Tornquist C. Paradoxos da humanização em uma maternidade no Brasil. Cad Saude Publica [Internet]. 2003 [cited 2016 Aug 24];19(Sup.2):S419-27. Available from: http://www.scielo.br/pdf/csp/v19s2/a23v19s2.pdf

40. Brüggemann MO, Ebsen ES, Ebele RR, Batista BD. Possibilidades de inserção do acompanhante no parto nas instituições públicas. Cienc Saude Colet [Internet]. 2016[cited 2016 Aug 24];21(8):2555-64. Available from: http://www.scielo.br/pdf/csc/v21n8/14138123-csc-21-08-2555.pdf

41. De Aguiar, JM, D'oliveira AFPL, Schraiber LB. Violência institucional, autoridade médica e poder nas maternidades sob a ótica dos profissionais de saúde. Cad Saude Publica[Internet]. 2013[cited 2016 Aug 24];29(11):2287-96. Available from: http://www. scielo.br/pdf/csp/v29n11/15.pdf

42. Busanello J, Kerber NPC, Lunardi Filho WD, Lunardi VL, Mendoza-Sassi RA, Azambuja EP, et al. Parto humanizado de adolescentes: concepção dos trabalhadores de saúde. Rev Enferm UERJ[Internet]. 2011 [cited 2017 Jan 03]; 19(2):218-23. Available from: http:// www.facenf.uerj.br/v19n2/v19n2a08.pdf

43. Resende LV, Rodrigues RN, Fonseca MC. Mortes maternas em Belo Horizonte, Brasil: percepções sobre qualidade da assistência e evitabilidade. Rev Panam Salud Publica[Internet]. 2015[cited 2016 Aug 24];37(4/5):218-24. Available from: https://pdfs. semanticscholar.org/4f54/0d85d475d0badf96a8d227f5eb82e2e518b0.pdf

44. Souza SRRK, Gualda DMR. A experiência da mulher e seu acompanhante no parto em uma maternidade pública. Texto Contexto Enferm [Internet]. 2016 [cited 2017 Jan 03]; 25(1):e4080014. Available from: http://www.scielo.br/pdf/tce/v25n1/en 0104-0707tce-25-01-4080014.pdf

45. Reis AE, Patrício ZM. Aplicação das ações preconizadas pelo Ministério da Saúde para o parto humanizado em um hospital de Santa Catarina. Cien Saude Colet[Internet]. 2005[cited 2016 Aug 24];10(Supl):221-30. Available from: http://www.scielo.br/pdf/ $\mathrm{csc} / \mathrm{v} 10 \mathrm{~s} 0 / \mathrm{a} 23 \mathrm{v} 10 \mathrm{~s} 0 . \mathrm{pdf}$

46. Lino HC, Diniz SG. "You take care of the baby's clothes and i take care of the delivery" communication between professionals and patients and decisions about the mode of delivery in the private sector in São Paulo, Brazil. Rev Bras Crescimento Desenvolv Hum[Internet]. 2015 [cited 2016 Sep 05];25(1):117-24. Available from: https://www.revistas.usp.br/jhgd/article/view/96825

47. Dreyfus HL, Rabinow P. Michael Foucault: uma trajetória filosófica para além do estruturalismo e da hermenêutica. Chigago: The University of Chicago, 1995.

48. Comitê Sobre A Eliminação Da Discriminação Contra As Mulheres (CEDAW). Comentários finais do Comitê sobre a Eliminação da Discriminação contra as Mulheres[Internet]. Brasil, 10 de agosto de 2007. [cited 2016 Sep 2]. Available from: http:/unesdoc. unesco.org/images/0013/001393/139389por.pdf

49. Pitter CP. Midwives' knowledge and attitudes when encountering Gender-Based Violence in their practice at a maternity hospital in Kingston, Jamaica. Int J Qual Stud Health Well-being[Internet]. 2016 [cited 2016 Sep 2];11:1-8. Available from: https://www. ncbi.nlm.nih.gov/pmc/articles/PMC4759831/

50. Narchi NZ. Análise do Exercício de Competências dos não Médicos para Atenção à Maternidade. Saude Soc[Internet]. 2010 [2016 Oct 07];19(1):147-58. Available from: http://www.scielo.br/pdf/sausoc/v19n1/12.pdf 